\title{
A Performance Evaluation of Ethical Mutual Funds: Evidence from India
}

\author{
Jasvinder Kaur ${ }^{\mathrm{a}} \bowtie$, Rashmi Chaudhary ${ }^{\mathrm{a}}$ \\ ${ }^{a}$ Department of Commerce, Kurukshetra University, India
}

\begin{abstract}
Since the last decade, ethical investment has gained significant development in the Indian financial market. With the increasing focus on social responsibility and the importance of ethical funds, investors pay more attention to the activities of these funds and their impact on society. Whether ethical fund investment affects portfolios' return performance is still questionable. To address this question, this paper investigated the performance of various ethical mutual fund schemes and compared them with benchmark index (NIFTY 500 Shariah Index) using data from 2014-15 to 2019-20. The performance of the sample schemes was measured based on the risk-return profile and Sharpe's ratio, Treynor's ratio and Jensen's alpha measures. The results indicated that nine out of ten ethical schemes outperformed the benchmark index during the study period. This implies that ethical funds generated positive returns with lower risk. As a policy implication, investment funds and financial institutions should develop fund schemes and stocks that incorporate ethical considerations in an investment.
\end{abstract}

Keywords: Ethical Investing, Risk Adjusted measures, Investment Performance, Mutual Funds

Received:

16 March 2021
Accepted revised version:

21 July 2021
Published:

31 December 2021

Suggested citation: Kaur, J. \& Chaudhary, R. (2021). A performance evaluation of ethical mutual funds: Evidence from India. Colombo Business Journal, 12(2), 1-22.

DOI: http://doi.org/10.4038/cbj.v12i2.78

(C2021 The Authors. This work is licensed under a Creative Commons Attribution 4.0 International License which permits unrestricted use, distribution, and reproduction in any medium, provided the original work is properly cited.

\Jasvinderkaurphd@kuk.ac.in (iD) https://orcid.org/0000-0001-9460-6537 


\section{Introduction}

The mutual fund industry provides a significant source of investment to both government and corporate entities. It pools and channelizes funds from savings units to deficit units (Mishra, 2012; Qureshi et al., 2019; Singh \& Kaur, 2021). In India, the mutual fund industry began with Unit Trust of India (UTI) in 1964. The mutual fund industry has undergone notable expansion since they were founded. From 1998 to 2003, the Indian mutual fund sector saw its net assets under management (AUM) grow by $60.28 \%$ (Mohanan, 2006). The reported AUM for 2019-20 is INR 222 million (The Securities and Exchange Board of India [SEBI], 2020). The gross fund raised by the Indian mutual fund industry has also been expanded, from INR 68,196.79 billion in 2011-12 to INR 188,134.58 billion in 2019-20 (SEBI, 2020). This industry's rise resulted from mutual funds' ability to enable small investors to invest their small surplus in securities. It could also be due to the deplorable state of the Indian financial system, which has seen several institutions merge or become bankrupt. That caused depositors to lose trust in banks, and they hunt for alternate ways to invest their spare money. As a result, the mutual fund sector provides them with an investing vehicle. Today, this industry offers many theme-based products, such as gold funds, exchange-traded funds, ethical funds, and others.

Over the last few decades, ethical or socially responsible investing has grown in popularity in the financial market. It has seen a considerable development due to large institutional investors embracing ethical investments (Sparkes \& Cowton, 2004). It is an investment strategy that endeavours to incorporate environmental and social benefits into a long-term investment plan, alongside traditional financial returns, to maximize social and financial rewards for investors (Brzeszczynski \& Mclntosh 2014). United States, Australia, the UK, and Spain have all established green, and sustainability-based funds, and indices. Vanguard FTSE Social Index, DAX Global Index, FTSE4 Environmental Index, US Large Cap ESG Index, and KLD Analytics are some indexes that build on sustainable and green index portfolio. Several studies on the performance of ethical stocks/funds (i.e., whether there is any difference in risk-returns of conventional and ethical investment) have been undertaken by various academics in various markets. Tippet (2001), Lozano et al. (2006), Mill (2006), Tripathi and Bhandari (2015), Cortez et al. (2009) are examples for such studies

In India, ethical investment is in its nascent stage. Bombay Stock Exchange (BSE) introduced two sustainable thematic indices in 2012, namely Greenex and Carbonex, while National Stock Exchange (NSE) introduced two thematic indices 
which were introduced in 2018: Nifty 100 ESG Index and Nifty 100 Enhanced ESG Index. India is backed by the first sustainable index 'Domini 400 Social Index'. This index was launched in 1990 to promote sustainable theme-based investment. Moreover, Indian financial institutions have not done much to develop ethical investment. According to SEBI (2019/2020) there were 1916 schemes, among which only 14 open-ended schemes were based on ethical principles. Out of the 44 mutual fund Assets Management Companies (AMC) in India only 3 companies provide ethical mutual fund schemes, namely, Taurus Mutual Fund, SBI Mutual Fund, and Tata Mutual Fund. However, ethics-based investing is gaining traction as a viable investment strategy and grows appreciably.

Considering the preceding explanation and the significance of study, the researchers formulate vital research questions such as (i) Does ethical screening in investing improve return performance? (ii) Is there any differential return between ethical investment and conventional investment? (iii) Is this alternate investment strategy secure, less risky, and capable of generating higher returns compared to conventional investment? To address these questions, this study aims to empirically investigate the performance of ethical mutual fund schemes in India and compare them to the Nifty 500 Shariah index.

This paper is organized as follows- The next section presents the literature review. This is followed data and methodology. and results and interpretation. In the final section concluding remarks and policy implications are suggested.

\section{Literature Review}

Ample literature is available on the performance evaluation of ethical funds, but most of the studies pertain to developed nations. The seminal work of Friend et al. (1962), who provided the first empirical evidence of mutual funds' performance, provoked interest among other researchers and academicians. After that, Treynor (1965), Sharpe (1966), and Jensen (1968) developed the standard models to measure risk adjusted performance of mutual funds. Ippolito (1989) examined the performance of 143 funds in the period 1965-1984 and concluded that funds with higher turnover and fees generated sufficient returns. Similarly, Sapar and Madava (2003) evaluated the performance of 58 mutual fund schemes in the bear market period from 1998-2002. They concluded that most of the funds provide an excess return over the expected return.

In the US, Goldreyer et al. (1999) compared the performance of 49 mutual funds with conventional funds using data from 1981 to 1997 using risk-adjusted 
measures. Results concluded that social screening does not significantly differ between ethical and conventional funds. Moreover, the author suggested that in some cases, screened funds outperformed unscreened funds. Similarly, Statman (2000) analyzed the performance of the Domini Social Index (an index of socially responsible companies) and socially responsible mutual funds. Jensen's alpha and Excess adjusted standard deviation's return (eSDAR) were applied on monthly data. The study found that both socially responsible funds and index performed better than the conventional funds and S\&P 500 index, respectively. Tippet (2001) conducted a study in Australia and analyzed the performance of returns of Australia's ethical funds to the market returns. Findings indicated that the mean rate of return realized by the ethical funds, was less than the expected rate and these funds underperformed by $1.5 \%$ per annum.

Utilizing Jensen's alpha and Carhart multi-factor model, Bauer et al. (2005) evaluated the performance of 103 German, US, and UK ethical funds. The study found no significant difference in risk-adjusted returns between ethical and conventional funds, suggesting the neutral performance between funds. Scholtens (2005) investigated the performance differential between socially responsible and conventional funds in the Netherlands. Weekly data was taken up and abovementioned techniques have been applied. The study concluded that there was no significant difference in the return performance of socially responsible funds and conventional funds. Mill (2006) scrutinized the financial performance of UK Unit trust that was initially based on conventional strategy and later acquired the ethical investment principles and converted them into ethical funds. The study found no evidence of under or over performance of funds. There was a similar performance between conventional principles-based investment and ethical principles-based investment.

The growth of socially responsible (SRI) mutual funds in the Spanish market was analyzed by Lozano et al. (2006), which demonstrated that this kind of market was underdeveloped. The author also analyzed the performance of SRI mutual funds and concluded that SRI funds generated negative returns, which indicates a poor performance of SRI mutual funds. Benson and Humphrey (2008) studied Australian funds to assess the determinants of fund flow of socially responsible investment and conventional funds, using descriptive statistics and the chi-square test. The findings identified that the average total net assets and flow of the socially responsible funds was higher than the conventional funds. Consolandi et al. (2008) investigated the reaction of the inclusion or deletion of stocks in the Dow Jones 
Sustainability Stock Index. Findings showed positive abnormal return performance for companies included in the index and vice-versa.

To determine whether the investment in ethical funds leads to a sacrifice or a premium, Fernandez-Izquierdo and Matallin-Saez (2008) compared the financial performance of ethical investment funds in the Spanish market. The result showed that ethical funds did not underperform the market, and in all cases, financial performance was superior or similar to benchmark indices. In Australia, Jones et al. (2008) assessed the performance of 89 ethical funds over the period from 1986 to 2005, using Jenson's alpha and multi-factor model. The results indicated that ethical funds significantly underperformed the market. Similarly, Cortez et al. (2009) investigated the performance of 88 socially responsible mutual funds of seven countries and concluded that social screening of mutual funds does not have a significant positive impact on returns. The author suggested that investors who hold European funds can add social screens to their portfolios without sacrificing their financial performance.

Using a sample of 23 ethical and 152 non-ethical funds throughout 2000-2007, Lundberg et al. (2009) examined the differences in risk-return profiles of ethical and non-ethical funds in Sweden. The study concluded that ethical funds generated higher systematic risk and underperformed when compared to non-ethical funds. Using matching estimator methodology throughout 1997-2005, Gil-Bazo et al. (2010) examined the before-fee and after-fee performance of socially responsible funds. The results revealed a superior risk-adjusted performance of socially responsible funds compared to conventional funds. Humphrey and Lee (2011) scrutinized the risk-return performance of socially responsible equity funds in the Australian market. Monthly data was considered from 1996 to 2008. They found no significant difference between the returns of socially responsible funds and conventional funds. Das and Rao (2013) analyzed the performance of socially responsible funds by using funds' investment styles. Using Sharpe's style analysis method, the study found that 75 mutual funds have an adverse selection Sharpe ratio, and 19 mutual funds have a positive selection Sharpe ratio. Results also reported that three fourth (3/4th) of socially responsible funds had negative performance relative to benchmark counterparts.

Brzeszczynski and Mclntosh (2014) investigated the performance of British socially responsible stocks throughout 2000-2010. They found that the socially responsible stocks generated higher average returns than market indexes, but these 
returns were statistically insignificant. In India, Tripathi and Bhandari (2015) examined the performance of ethical funds from 2009 to 2014, utilizing riskadjusted performance measures. The study concluded that ethical funds generated higher returns and outperformed the market index. The study further suggested that the growth rate of ethical funds was also higher. Nainggolan et al. (2016) evaluated the performance of ethically screened Islamic funds for the period 1984-2010. Their results concluded that Islamic ethical funds underperformed when compared to the conventional funds.

Matallín-Saez et al. (2019) analyzed the risk-adjusted performance of mutual funds that integrate socially responsible screening criteria. For this purpose, a sample of 3920 funds across the world covering the data for 18 years was used. The study concluded that there was no significant higher return performance of screened funds. Azmi et al. (2020) investigated the financial performance of 964 ethical mutual funds in different regions covering the period from 2002 to 2013. The data were analyzed through Jensen's alpha and multi-factor model. The study's findings revealed the underperformance of ethical funds, indicating that screening has a negative impact on funds' performance.

\section{Methodology Used in Existing Literature}

There are various techniques to measure the performance of mutual funds. Different studies used numerous techniques considering study's objectives and data availability. A summary of methodologies used in the previous studies is demonstrated in Table 1 given below.

Table 1: Previously used Methodologies

\begin{tabular}{ll}
\hline Technique/s & Author/s \\
\hline $\begin{array}{l}\text { Sharpe ratio, Treynor ratio, Jensen's alpha } \\
\text { and Fama's measure }\end{array}$ & $\begin{array}{l}\text { Goldreyer et al. (1999); Sapar and Madava } \\
(2003) ; \text { Lundberg et al. (2009); Tripathi and } \\
\text { Bhandari (2015); Nainggolan et al. (2016) } \\
\text { Bharpe ratio, Fama's measures and }\end{array}$ \\
$\begin{array}{l}\text { Carhart's four factor model } \\
\text { Jensen's alpha and Carhart multi-factor } \\
\text { model }\end{array}$ & $\begin{array}{l}\text { Bauer et al. (2005); Scholtens (2005); Jones } \\
\text { et al. (2008); Humphrey and Lee (2011); }\end{array}$ \\
& $\begin{array}{l}\text { Azmi et al. (2020) } \\
\text { Jensen's alpha measures }\end{array}$ \\
& Statman (2000); Tippet (2001); Cortez et al. \\
& $(2009)$ \\
\hline
\end{tabular}




\begin{tabular}{ll}
\hline Technique/s & Author/s \\
\hline Carhart multi-factor model & Fernandez-Izquierdo and Matallin-Saez \\
& (2008); Gil-Bazo et al. (2010); Humphrey \\
& and Lee (2011); Matallín-Saez et al. (2019) \\
Sharpe ratio & Lozano et al. (2006); Consolandi et al. \\
& (2008); Das and Rao (2013) \\
\hline
\end{tabular}

From the above-discussed literature review, it is clear that various studies are available on ethical fund performance. However, previous studies provide mixed and inconclusive results, for example, outperformance (Consolandi et al., 2008; GilBazo et al., 2010; Statman, 2000; Tripathi and Bhandari, 2015), underperformance (Azmi et al., 2020; Das \& Rao, 2013; Jones et al., 2008; Tippet, 2001; ) and neutral performance (Goldreyer et al., 1999; Matallín-Saez et al., 2019; Mill, 2006; Scholtens, 2005).Moreover, all available literature target the developed nations viz. US, UK, Australia, and Spain. Nevertheless, in India, relatively little evidence exists of ethical investments' performance because the concept of ethical investment is still in the developing stage in the Indian stock market. Therefore, to bridge the gap, there is a need to undertake a study on ethical funds.

\section{Data and Methodology}

\section{Data and Sources}

To accomplish the study's objective of whether there is any performance difference between ethical funds and benchmark market index, data of ten ethical fund schemes for the period of six years (2014/15 to 2019/20) was collected. As previously stated in the introduction, only three AMCs viz. Taurus mutual fund, Tata mutual fund, and SBI mutual funds provide ethics-based fund schemes. SBI mutual funds schemes were removed from the sample due to the non-availability of data for the selected study period. Therefore, the sample is reasonably representative of the ethical mutual fund schemes. The sample schemes are illustrated in Table 2. The schemes' daily closing Net Asset Value (NAV) is obtained from the website of Association of Mutual Funds in India (AMFI) ${ }^{1}$ NIFTY 500 Shariah index has been taken as a benchmark market index, and the daily adjusted closing prices of the same market index were taken from the website of $\mathrm{NSE}^{2}$. Daily closing NAVs/prices are used to capture the daily fluctuations like effect of corporate events, which cannot be reflected in monthly and annual data.

\footnotetext{
${ }^{1}$ www.amfiindia.com

${ }^{2}$ www.nseindia.com
} 
Moreover, daily prices can provide insights for more reliable results and help in making policy decisions. The 91-days treasury bills rate has been used as a proxy for the risk-free rate and collected from the website of Reserve Bank of India ${ }^{1}$.

Table 2: List of Selected Ethical Schemes ${ }^{2}$

\begin{tabular}{ll}
\hline Taurus Mutual Fund Schemes & Tata Mutual Fund Schemes \\
\hline Taurus Ethical Growth - Direct Plan & Tata Ethical Growth - Direct Plan \\
Taurus Ethical Dividend- Direct plan & Tata Ethical Dividend- Direct plan \\
Taurus Ethical Growth- Regular Plan & Tata Ethical Growth- Regular Plan \\
Taurus Ethical Dividend- Regular Plan & Tata Ethical Dividend- Regular Plan \\
Taurus Ethical Bonus- Direct Plan & \\
Taurus Ethical Bonus- Regular Plan & \\
\hline
\end{tabular}

\section{Methodology}

The empirical analysis consists of risk-return analysis and performance evaluation of ethical mutual fund schemes and benchmark index. Most previous studies on the performance evaluation of mutual funds use the Capital Assets Pricing Model (CAPM), Sharpe ratio, Treynor ratio and Jensen's alpha measure (for example: Goldreyer et al., 1999; Humphrey \& Lee, 2011; Lundberg et al., 2009; Sapar \& Madava, 2003; Tripathi \& Bhandari, 2015). Treynor ratio (Treynor, 1965) uses systematic risk (measured by Beta) for performance evaluation. It would be the best measure for a fully diversified portfolio in which the relevant measure of risk is systematic as all unsystematic risk would be diversified away. On the other hand, Sharpe ratio (Sharpe, 1966) uses the total risk (systematic as well as unsystematic risk) measured by standard deviation. It would be appropriate for the nondiversified portfolio; however, it is not very informative as it is based on total risk of the portfolio and does not explore the per unit risk in a portfolio for excess returns. Therefore, according to portfolio type (whether diversified or not), these ratios can be used. Jensen's alpha (Jensen, 1968) measures the differential return (i.e. alpha) between the expected and actual returns of the portfolio. Differential return gives an indication of the portfolio's manager's managerial skills and predictive abilities. It provides information to investors about the portfolio's performance: whether portfolio is outperformed or underperformed or performed at par with market. The alpha value can be used to rank the portfolios as well managers of the portfolios. Thus, the present study employs the widely accepted measures, namely, Sharpe Ratio, Treynor Ratio, and Jensen's alpha as performance

\footnotetext{
${ }^{1}$ www.rbi.org.in

${ }^{2}$ www.amfiindia.com
} 
evaluation measures. The formulas' specifications of measures used in the study are as follows:

Return. Net Asset Value (NAV) is the most widely used measure for measuring the performance of mutual funds as sale and purchase prices are linked to NAVs. It is the market value of the funds' assets (includes cash, dividends, and capital appreciation) minus its liabilities. Therefore, in this study, daily closing NAVs are used for the computation of the scheme return. For getting the Annualized Scheme Return (ASR) the sum of daily returns is taken. Daily returns are computed as:

$$
D S R_{i, d}=\frac{N A V_{i, d}-N A V_{i, d-1}}{N A V_{i, d-1}}
$$

where $D S R_{i, d}=$ Daily return of $i^{\text {th }}$ scheme at day $d, N A V_{i, d}=N A V$ of $i^{\text {th }}$ scheme at day $d, N A V_{i, d-1}=N A V$ of $i^{\text {th }}$ scheme at day $d-1$.

$$
A S R_{i, y}=\sum_{d=1}^{i} D S R_{i, d}
$$

where $A S R_{i, y}=$ Annualized return of $i^{\text {th }}$ scheme at year $y$

Similarly, Annualized Market Returns (AMR) are computed for the NIFTY 500 Shariah Index as a benchmark. Daily adjusted closing prices are used for getting market return since adjusted closing prices reflect the stock's value after adjusting for corporate events such as dividends, right issue and stock splits.

The return on market index is computed as:

$$
D M R_{d}=\frac{P_{d}-P_{d-1}}{P_{d-1}}
$$

where $D M R_{d}=$ Daily return of market at day $d, P_{d}=$ price of market at day $d, P_{d-1}$ $=$ price of market at day $d-1$

$$
A M R_{y}=\sum_{d=1}^{i} D M R_{d}
$$

where $A M R_{y}=$ Annualized return of market at year $y$

Standard deviation. It is a measure of volatility in return. A higher value of standard deviation indicates higher risk.

$$
\sigma=\sqrt{\frac{\sum\left(A S R_{i, y}-\overline{A S R}_{i, y}\right)^{2}}{n-1}}
$$


where $\sigma=$ symbol of standard deviation, $A S R_{i, y}=$ Annualized return of $i^{\text {th }}$ scheme at year $y, \overline{A S R}_{i, y}=$ Annualized mean return of the $i^{\text {th }}$ scheme at year $y$.

Beta. Beta measures the systematic risk. It is the funds' normalized covariance with market movements and relates the return of the fund to the market index. A beta greater than one means that fund is more volatile than the benchmark index. The statistics model used for beta measurement is computed as follows:

$$
\beta=\frac{\text { Covariance }\left(A S R_{i, y}, A M R_{y}\right)}{\text { Variance }\left(A M R_{y}\right)}
$$

Sharpe ratio. It is a risk-adjusted performance measure developed by Sharpe (1966).It is the ratio of the risk premium (difference between portfolio return and risk-free return) to the standard deviation of the portfolio. It is also known as the Reward to variability ratio. It can be calculated as:

$$
\text { Sharpe Ratio }=\frac{A S R_{i, y}-A R F_{y}}{\sigma_{i, y}}
$$

where $A S R_{i, y}=$ Annualized return of $i^{\text {th }}$ scheme at year $y, A R F_{y}=$ Annualized riskfree rate of year $y, \sigma_{i, y}=$ Annualized standard deviation of $i^{\text {th }}$ scheme at year $y$

Treynor ratio. It was developed by Treynor (1965) and referred to as 'reward to volatility ratio'. It is the ratio of the risk premium to the portfolio beta. It can be calculated as:

$$
\text { Treynor Ratio }=\frac{A S R_{i, y}-A R F_{y}}{\beta_{i, y}}
$$

where $A S R_{i, y}=$ Annualized return of $i^{\text {th }}$ scheme at year $y, A R F_{i, y}=$ Annualized risk-free rate of year $y, \beta_{i, y}=$ Beta of the $i^{\text {th }}$ scheme at year $y$.

Jensen's alpha. It is the most used measure that calculates the differential return of the portfolio, i.e., alpha. The value of the alpha helps in identifying the manager's ability of stock selection and thereby earning excess return than benchmark index. It is popularly known as Jensen's alpha (1968). The differential returns, i.e., alpha can be calculated as:

$$
\alpha=\left(A S R_{i, y}-A R F_{y}\right)-\beta_{i, y}\left(A M R_{y}-A R F_{y}\right)
$$


where $\alpha=$ alpha (Jensen's measure), $A S R_{i, y}=$ Annualized return of $i^{\text {th }}$ scheme at year $y, A M R_{y}=$ Annualized return of the market at year $y, A R F_{y}=$ Annualized riskfree rate of year $y, \beta_{i, y}=$ Beta of the $i^{\text {th }}$ scheme at year $y$

Comparative performance t-test. To check whether there is any significant difference between returns of different ethical schemes and benchmark Nifty 500 Shariah index, $t$-test used.

$$
t=\frac{\overline{A S R_{l, y}}-\overline{A M R_{y}}}{\sqrt{\frac{s_{1}^{2}}{n_{1}}+\frac{s_{2}^{2}}{n_{2}}}}
$$

where $\overline{A S R_{l, y}}$ and $\overline{A M R_{y}}=$ Annualized returns of ethical scheme and benchmark index, $s_{1}$ and $s_{2}=$ Standard deviation of ethical scheme and benchmark index, $n_{1}$ and $n_{2}=$ number of observations in ethical scheme and benchmark index.

\section{Results and Interpretation}

\section{Risk-Return Profile of Different Ethical Schemes and Benchmark Index}

Table 3 exhibits the risk-return profile of various ethical fund schemes, i.e., Tata ethical fund schemes, Taurus ethical fund schemes, and Nifty 500 Shariah benchmark index. The analysis in Table 3 shows that all the schemes and benchmarks provide positive returns, and most of the schemes generated higher returns than the benchmark market index. The maximum return of 0.09048 was generated by the Taurus Ethical Growth- Direct Plan scheme, whereas Tata Ethical Dividend Fund generated the minimum return of 0.02447. Among all the schemes, nine out of ten recorded higher returns than the benchmark portfolio. However, standard deviation, which is a measure of absolute risk, indicates that all schemes had less risk than the benchmark except the Tata Ethical Dividend scheme which reported a high standard deviation of 0.14670 . The remaining ethical schemes have a lower standard deviation from the benchmark.

Interestingly, when we observed the coefficient of variation, a relative measure of risk, the Tata Ethical Dividend scheme provided the highest coefficient (5.99511), followed by the benchmark index coefficient with 1.79667. It reflected that the Tata Ethical Dividend scheme is the riskiest one among all other schemes. The beta of various ethical schemes was less than the benchmark index, i.e., the Nifty 500 Shariah index. 
Table 3: Risk- Return Profile of Different Ethical Schemes and Benchmark Index

\begin{tabular}{lrrrr}
\hline \multicolumn{1}{c}{ Schemes } & Return & $\begin{array}{c}\text { Standard } \\
\text { Deviation }\end{array}$ & $\begin{array}{c}\text { Coefficient } \\
\text { of } \\
\text { Variation }\end{array}$ & Beta \\
\hline Taurus Ethical Fund - (Bonus) & 0.0824 & 0.13424 & 1.62914 & 0.85939 \\
Taurus Ethical Fund - (Growth) & 0.08245 & 0.13433 & 1.62928 & 0.85503 \\
Taurus Ethical Fund - (Dividend) & 0.08256 & 0.13437 & 1.62752 & 0.85507 \\
Taurus Ethical Fund - (Bonus) - & 0.07582 & 0.13443 & 1.77291 & 0.82957 \\
$\begin{array}{l}\text { Direct Plan } \\
\text { Taurus Ethical Fund - (Growth) - }\end{array}$ & 0.09048 & 0.13435 & 1.48493 & 0.76388 \\
$\begin{array}{l}\text { Direct Plan } \\
\text { Taurus Ethical Fund - (Dividend) - }\end{array}$ & 0.08994 & 0.13434 & 1.49354 & 0.85529 \\
Direct Plan & 0.07657 & 0.12815 & 1.6737 & 0.84831 \\
Tata Ethical Fund - (Growth) & 0.02447 & 0.1467 & 5.99511 & 0.8735 \\
Tata Ethical Fund - (Dividend) & 0.08628 & 0.12815 & 1.4853 & 0.84847 \\
Tata Ethical Fund - (Growth) - Direct & & 0.13213 & 1.846 & 0.85788 \\
Plan & 0.07158 & 0.14308 & 1.79667 & 1 \\
\hline $\begin{array}{l}\text { Tata Ethical Fund - (Dividend) - } \\
\text { Direct Plan }\end{array}$ & 0.07964 & 0 & & \\
NIFTY 500 Shariah Index & & & & \\
\hline
\end{tabular}

Tata Ethical Dividend Scheme had the most negligible beta value among all ethical fund schemes. It indicates that the Tata Ethical Dividend scheme is less sensitized to market conditions than other schemes. These results are corroborated with Statman (2000), Cortez et al. (2009), and Brzeszczynski and Mclntosh (2014). Overall, it can be concluded that ethical schemes outperformed the benchmark Nifty 500 Shariah Index based on the risk-return profile. It suggested that investment in ethical fund schemes can be the best avenue for investors who are concerned with ethics to allocate their resources to ethics-based stocks/funds.

\section{Sharpe Ratio of Different Ethical Schemes and Benchmark Index}

Table 4 presents the performance of various ethical schemes and benchmark indexes based on Sharpe ratio. Table 4 shows that in the year 2014-15, all ethical schemes outperformed the market index except the Tata Ethical Dividend fund. However, in 2015-16 and 2016-17, all schemes have less return than benchmark portfolios. This underperformance was due to demonetization in November 2016. Again in 2017-18, all proxies of ethical schemes generated higher returns than the benchmark index (Nifty 500 Shariah Index). As we look at the values of 2019-20, Sharpe ratio for all schemes and benchmark index were negative. In the study, the 
average return was positive for all schemes. Taurus Ethical Growth and DividendDirect Plan schemes recorded the highest return with 0.3867 and 0.3826 , respectively.

Table 4: Sharpe Ratio of Different Ethical Schemes and Benchmark Index

\begin{tabular}{|c|c|c|c|c|c|c|c|}
\hline Schemes & 2014-15 & 2015-16 & 2016-17 & 2017-18 & 2018-19 & 2019-20 & $\begin{array}{c}\text { Avg. } \\
\text { Value }\end{array}$ \\
\hline $\begin{array}{l}\text { Taurus Ethical } \\
\text { Fund - (Bonus) }\end{array}$ & 2.5663 & -1.1677 & 0.6033 & 0.8218 & 0.0255 & -0.8997 & 0.3249 \\
\hline $\begin{array}{l}\text { Taurus Ethical } \\
\text { Fund - (Growth) }\end{array}$ & 2.5592 & -1.1663 & 0.6059 & 0.8213 & 0.0237 & -0.8982 & 0.3243 \\
\hline $\begin{array}{l}\text { Taurus Ethical } \\
\text { Fund - (Dividend) }\end{array}$ & 2.5625 & -1.1643 & 0.6062 & 0.8207 & 0.0253 & -0.8948 & 0.3259 \\
\hline $\begin{array}{l}\text { Taurus Ethical } \\
\text { Fund - (Bonus) - } \\
\text { Direct Plan }\end{array}$ & 1.9084 & -1.1269 & 0.6711 & 0.9014 & 0.0951 & -0.8531 & 0.2660 \\
\hline $\begin{array}{l}\text { Taurus Ethical } \\
\text { Fund - (Growth) - } \\
\text { Direct Plan }\end{array}$ & 2.5971 & -1.1149 & 0.6887 & 0.8976 & 0.1068 & -0.8549 & 0.3867 \\
\hline $\begin{array}{l}\text { Taurus Ethical } \\
\text { Fund - (Dividend) } \\
\text { - Direct Plan }\end{array}$ & 2.5911 & -1.1259 & 0.6772 & 0.8991 & 0.1086 & -0.8545 & 0.3826 \\
\hline $\begin{array}{l}\text { Tata Ethical Fund } \\
\text { - (Growth) }\end{array}$ & 2.8210 & -0.9055 & 0.3732 & 0.7414 & -0.3974 & -0.9492 & 0.2806 \\
\hline $\begin{array}{l}\text { Tata Ethical Fund } \\
\text { - (Dividend) }\end{array}$ & 1.5628 & -1.2945 & 0.3729 & -0.0293 & -0.8667 & -0.9498 & -0.2008 \\
\hline $\begin{array}{l}\text { Tata Ethical Fund } \\
\text { - (Growth) - } \\
\text { Direct Plan }\end{array}$ & 2.9038 & -0.8379 & 0.4352 & 0.8498 & -0.2952 & -0.8960 & 0.3599 \\
\hline $\begin{array}{l}\text { Tata Ethical Fund } \\
\text { - (Dividend) - } \\
\text { Direct Plan }\end{array}$ & 2.8999 & -0.8379 & 0.4347 & 0.5380 & -0.6906 & -0.8962 & 0.2413 \\
\hline $\begin{array}{l}\text { NIFTY } 500 \\
\text { Shariah Index }\end{array}$ & 1.6123 & -0.5247 & 1.1895 & 0.8673 & -0.3551 & -1.0297 & 0.2933 \\
\hline
\end{tabular}

Tata Ethical Dividend Scheme showed a minimum return of 0.2008. These findings are similar to the findings of Das and Rao (2013), Tripathi and Bhandari (2015), and Traaseth and Framstad (2016). Overall, during the study period, Taurus Ethical Schemes outperformed the benchmark index. This suggested that despite the risk schemes generating more return, there was no penalty for investing in ethical funds. 


\section{Treynor Ratio of Different Ethical Schemes and Nifty 500 Shariah Benchmark}

\section{Index}

Table 5 exhibits the results of Treynor ratio. The Treynor ratio measures the return per unit to systematic risk, i.e., beta. Thus, a higher Treynor ratio demonstrates higher return per unit to total systematic risk. As per Treynor ratio, in 2014-15, Tata Ethical Growth and Dividend Schemes- Direct Plan achieved the highest return of 0.3923 and 0.3918 , respectively. Surprisingly, in 2015-16, fund return, and benchmark index return were negative and ethical funds underperformed the benchmark portfolio. In 2018-19, all Taurus ethical schemes outperformed, and all Tata ethical schemes underperformed compared to benchmark Nifty 500 Shariah index. It may be due to the least diversification availability. Moreover, we found that nine out of ten schemes have a higher return than index return when we look at the average return. Applying the Treynor ratio, we conclude that the majority of the schemes outperformed the benchmark index. The study results are corroborated with the Goldreyer et al. (1999), Sapar and Madava (2003), and Kreander et al. (2005).

Table 5: Treynor Ratio of Various Ethical Schemes and Benchmark Index

\begin{tabular}{lccccccc}
\hline \multicolumn{1}{c}{ Schemes } & $\mathbf{2 0 1 4 - 1 5}$ & $\mathbf{2 0 1 5 - 1 6}$ & $\mathbf{2 0 1 6 - 1 7}$ & $\mathbf{2 0 1 7 - 1 8}$ & $\mathbf{2 0 1 8 - 1 9}$ & $\mathbf{2 0 1 9 - 2 0}$ & $\begin{array}{c}\text { Avg. } \\
\text { Value }\end{array}$ \\
\hline $\begin{array}{l}\text { Taurus Ethical } \\
\text { Fund - (Bonus) }\end{array}$ & 0.3513 & -0.1993 & 0.0764 & 0.0985 & 0.0038 & -0.2052 & 0.0209 \\
$\begin{array}{l}\text { Taurus Ethical } \\
\text { Fund - (Growth) }\end{array}$ & 0.3504 & -0.1992 & 0.0767 & 0.0984 & 0.0036 & -0.2117 & 0.0197 \\
$\begin{array}{l}\text { Taurus Ethical } \\
\text { Fund - (Dividend) }\end{array}$ & 0.3511 & -0.1989 & 0.0767 & 0.0984 & 0.0038 & -0.2108 & 0.0201 \\
$\begin{array}{l}\text { Taurus Ethical } \\
\text { Fund - (Bonus) - }\end{array}$ & 0.3303 & -0.1924 & 0.0852 & 0.1081 & 0.0143 & -0.1947 & 0.0251 \\
$\begin{array}{l}\text { Direct Plan } \\
\text { Taurus Ethical }\end{array}$ & & & & & & & \\
$\begin{array}{l}\text { Fund - (Growth) - } \\
\text { Direct Plan }\end{array}$ & 0.3558 & -0.1904 & 0.2250 & 0.1076 & 0.0160 & -0.2014 & 0.0521 \\
$\begin{array}{l}\text { Taurus Ethical } \\
\text { Fund - (Dividend) } \\
- \text { Direct Plan }\end{array}$ & 0.3547 & -0.1922 & 0.0858 & 0.1077 & 0.0162 & -0.2014 & 0.0285 \\
$\begin{array}{l}\text { Tata Ethical Fund } \\
\text { (Growth) }\end{array}$ & 0.3813 & -0.1515 & 0.0472 & 0.0830 & -0.0547 & -0.2125 & 0.0155 \\
$\begin{array}{l}\text { Tata Ethical Fund } \\
\text {-(Dividend) }\end{array}$ & 0.2579 & -0.2458 & 0.0471 & -0.0041 & -0.1418 & -0.2126 & -0.0499 \\
\hline
\end{tabular}




\begin{tabular}{|c|c|c|c|c|c|c|c|}
\hline Schemes & 2014-15 & $2015-16$ & 2016-17 & $2017-18$ & 2018-19 & $2019-20$ & $\begin{array}{l}\text { Avg. } \\
\text { Value }\end{array}$ \\
\hline $\begin{array}{l}\text { Tata Ethical Fund } \\
\text { - (Growth) - } \\
\text { Direct Plan }\end{array}$ & 0.3923 & -0.1402 & 0.0550 & 0.0951 & -0.0406 & -0.2006 & 0.0268 \\
\hline $\begin{array}{l}\text { Tata Ethical Fund } \\
\text { - (Dividend) - } \\
\text { Direct Plan }\end{array}$ & 0.3918 & -0.1402 & 0.0549 & 0.0623 & -0.1049 & -0.2006 & 0.0105 \\
\hline $\begin{array}{l}\text { NIFTY } 500 \\
\text { Shariah Index }\end{array}$ & 0.1967 & -0.0837 & 0.1401 & 0.0920 & -0.0472 & -0.2266 & 0.0119 \\
\hline
\end{tabular}

\section{Jensen's Alpha Measure of Different Ethical Schemes}

Table 6 exhibits the performance of schemes according to Jenson measure. Jenson's alpha measure of risk-adjusted measure manifests the abnormal return of fund schemes. The results reported that in the year 2014-15 and 2019-20, all proxies of ethical funds had offered positive alpha values indicating the superior performance and good managerial ability of fund managers. These outcomes are in line with Mallin et al. (1995), Gil-Bazo et al. (2010), and Hili et al. (2016). However, in 2015-16 and 2016-17, none of the schemes have a positive alpha. It may be an effect of the economic slowdown due to demonetization in 2016. Based on 6 years' average alpha values, the analysis reflects that the Taurus Ethical Growth fund- Direct Plan generates the highest alpha, i.e., 0.0252. In contrast, Tata Ethical Dividend Scheme has a negative alpha, i.e., -0.0524, indicating the fund manager's inferior performance and poor managerial skills.

Table 6: Jensen's Alpha of Different Ethical Schemes

\begin{tabular}{lccccccc}
\hline \multicolumn{1}{c}{ Schemes } & $\mathbf{2 0 1 4 - 1 5}$ & $\mathbf{2 0 1 5 - 1 6}$ & $\mathbf{2 0 1 6 - 1 7}$ & $\mathbf{2 0 1 7 - 1 8}$ & $\mathbf{2 0 1 8 - 1 9}$ & $\mathbf{2 0 1 9 - 2 0}$ & $\begin{array}{c}\text { Avg. } \\
\text { Value }\end{array}$ \\
\hline $\begin{array}{l}\text { Taurus Ethical } \\
\text { Fund - (Bonus) }\end{array}$ & 0.1349 & -0.1081 & -0.0572 & 0.0052 & 0.0387 & 0.0190 & 0.0054 \\
$\begin{array}{l}\text { Taurus Ethical } \\
\text { Fund - (Growth) }\end{array}$ & 0.1345 & -0.1080 & -0.0568 & 0.0052 & 0.0385 & 0.0128 & 0.0044 \\
$\begin{array}{l}\text { Taurus Ethical } \\
\text { Fund - (Dividend) }\end{array}$ & 0.1348 & -0.1079 & -0.0569 & 0.0051 & 0.0387 & 0.0136 & 0.0046 \\
$\begin{array}{l}\text { Taurus Ethical } \\
\text { Fund - (Bonus) - } \\
\text { Direct Plan }\end{array}$ & 0.0917 & -0.1018 & -0.0494 & 0.0129 & 0.0466 & 0.0283 & 0.0047 \\
\hline
\end{tabular}




\begin{tabular}{lccccccc}
\hline \multicolumn{1}{c}{ Schemes } & $\mathbf{2 0 1 4 - 1 5}$ & $\mathbf{2 0 1 5 - 1 6}$ & $\mathbf{2 0 1 6 - 1 7}$ & $\mathbf{2 0 1 7 - 1 8}$ & $\mathbf{2 0 1 8 - 1 9}$ & $\mathbf{2 0 1 9 - 2 0}$ & $\begin{array}{c}\text { Avg. } \\
\text { Value }\end{array}$ \\
\hline $\begin{array}{l}\text { Taurus Ethical } \\
\text { Fund - (Growth) - }\end{array}$ & 0.1393 & -0.0998 & 0.0294 & 0.0125 & 0.0480 & 0.0217 & 0.0252 \\
$\begin{array}{l}\text { Direct Plan } \\
\text { Taurus Ethical }\end{array}$ & 0.1385 & -0.1015 & -0.0486 & 0.0126 & 0.0482 & 0.0217 & 0.0118 \\
$\begin{array}{l}\text { Fund - (Dividend) - } \\
\text { Direct Plan }\end{array}$ & & & & & & & \\
$\begin{array}{l}\text { Tata Ethical Fund - } \\
\text { (Growth) }\end{array}$ & 0.1454 & -0.0534 & -0.0777 & -0.0082 & -0.0063 & 0.0130 & 0.0022 \\
$\begin{array}{l}\text { Tata Ethical Fund - } \\
\text { (Dividend) }\end{array}$ & 0.0522 & -0.1255 & -0.0777 & -0.0910 & -0.0855 & 0.0129 & -0.0524 \\
$\begin{array}{l}\text { Tata Ethical Fund - } \\
\text { (Growth) - Direct }\end{array}$ & 0.1542 & -0.0445 & -0.0711 & 0.0028 & 0.0056 & 0.0241 & 0.0118 \\
$\begin{array}{l}\text { Plan } \\
\text { Tata Ethical Fund - } \\
\text { (Dividend) - Direct }\end{array}$ & 0.1537 & -0.0445 & -0.0712 & -0.0274 & -0.0513 & 0.0240 & -0.0027 \\
Plan & & & & & & & \\
\hline
\end{tabular}

\section{Results of Test- Differential Mean of Different Ethical Schemes with Respect to Benchmark Index}

Table 7 shows the results of the $t$-test. This test was performed to verify any differential return of ethical schemes from the Nifty 500 Shariah benchmark index. Based on the results, a conclusion can be drawn that out of ten schemes, only six schemes generated higher differential returns than the benchmark index. However, the differential means were not statistically significant and diverse from zero. These results are in line with Bauer et al. (2005), Tripathi and Bhandari (2015), and Matallín-Saez et al. (2019). This may be due to the small size of these ethical funds, as in India, ethical investment is still in the incipient stage.

Moreover, the returns of four schemes, namely, Taurus Ethical (DP)-Dividend, Tata Ethical-Growth, Tata Ethical-Dividend, Tata Ethical (DP)-Dividend, were lower than Nifty 500 Shariah. Only the Tata Ethical Fund- Dividend has a low differential return $(-0.02252)$ than the benchmark index return, and the difference was statistically significant at $10 \%$. The growth and Dividend scheme's returns of the Taurus Ethical Fund were higher by 0.00442 (p-value 0.6523) and 0.00420 (pvalue 0.6683 ), respectively. This higher differential return performance suggests that now the corporate and fund houses pay attention to ethical issues and gives due importance to responsible and ethics-based business activities. Moreover, investors 
who have more faith in ethics can freely apply ethical screening while making investment portfolios without sacrificing a return performance.

Table 7: Results of $\boldsymbol{t}$-test- Comparison of Different Ethical Schemes with Nifty 500 Shariah

\begin{tabular}{lccc}
\hline \multicolumn{1}{c}{ Pairs } & $\begin{array}{c}\text { Differential } \\
\text { Mean }\end{array}$ & $\boldsymbol{t}$-value & $\boldsymbol{p}$-value \\
\hline Taurus Ethical Fund - (Bonus) & 0.00112 & 0.12319 & 0.90198 \\
Taurus Ethical Fund - (Growth) & 0.00115 & 0.11674 & 0.90708 \\
Taurus Ethical Fund - (Dividend) & 0.00119 & 0.12134 & 0.90344 \\
Taurus Ethical Fund - (Bonus) - Direct Plan & -0.00161 & -0.15450 & 0.87724 \\
Taurus Ethical Fund - (Growth) - Direct Plan & 0.00442 & 0.45063 & 0.65233 \\
Taurus Ethical Fund - (Dividend) - Direct Plan & 0.00420 & 0.42846 & 0.66838 \\
Tata Ethical Fund - (Growth) & -0.00125 & -0.17162 & 0.86376 \\
Tata Ethical Fund - (Dividend) & $-0.02252 *$ & -1.76282 & 0.07814 \\
Tata Ethical Fund - (Growth) - Direct Plan & 0.00271 & 0.37154 & 0.71029 \\
Tata Ethical Fund - (Dividend) - Direct Plan & -0.00329 & -0.38890 & 0.69741 \\
\hline
\end{tabular}

\section{Conclusion and Policy Implications}

The present paper investigated the performance of ethical mutual fund schemes of Tata and Taurus mutual fund companies and compared them with benchmark index NIFTY 500 Shariah index for the period from 2014-15 to 2019-20. The sample ethical schemes' performances were evaluated by administering the Sharpe ratio, Treynor ratio, and Jensen's Alpha on the selected period. The study found that nine out of ten ethical schemes generated a higher and positive return. This implies that despite the higher risk, almost all ethical fund schemes outperformed their benchmark index. The results of the study are consistent with the findings of Fernandez- Izquierdo and Matallin-Saez (2008), Gil-Bazo et al. (2010), Brzeszczynski and Mclntosh (2014), and Tripathi and Bhandari (2015). Only the Tata Ethical Dividend schemes generated a lower return and underperformed the benchmark. It may be because these schemes face diversification issues. However, our study does not lend support to the notion that ethical screening leads to poor performance.

As a policy implication, based on the study's findings, investment funds and financial institutions should develop schemes and stocks that incorporate ethical considerations in investment. This may equip policymakers to make well-informed 
decisions such as ensuring allocation of scant resources in ethics-based projects, enforcing CSR law and pushing financial reforms in the direction of ethical investment. Investors can utilize these findings to modify their portfolios. They can invest their money in ethical funds, for example, Taurus growth ethical schemes, Taurus dividend ethical schemes, Taurus bonus ethical schemes, and Tata growth ethical schemes, and earn high returns without being concerned about underperformance. Additionally, investors who are socially responsible and consider their investment's impact on society can consider ethics-based investment as the best trading strategy for investment.

The current study is not free from certain limitations. (i) The analysis is based on a restricted period data. A more extended period data could provide more robust results. (ii) The datasets of ethical mutual fund schemes are relatively small, consisting of only ten ethical schemes. (iii) This study includes only ethical schemes. A comparative analysis of ethical fund schemes with general fund schemes is possible (iv) Transaction cost, managers' fees, and tax are not considered, although it also affects the performance of mutual fund schemes. (v) Lastly, the present study is entirely focused on the Indian market without considering the international market.

Regarding the scope for further research, an analysis can be done under various economic conditions across different countries. Second, other performance evaluation measures like information ratio, $\mathrm{M}^{2}$ measure (Modigilani-Modigilani measure) (Miller and Modigiliani, 1961), and Fama-french model (Fama et al., 1993) can calculate return performance. Furthermore, a preliminary data-based study can be done to know the investors' perception of responsible investment.

\section{Declaration of Conflicting Interests}

The authors declared no potential conflicts of interest with respect to the research, authorship, and publication of this article.

\section{Acknowledgement}

The researchers duly acknowledge the contribution of the reviewers by sharing their valuable comments and suggestions which helped to improve the quality of the research article. 


\section{References}

Azmi, W., Mohamad, S., \& Shah, M. E. (2020). Ethical investments and financial performance: International evidence. Pacific-Basin Finance Journal, 62, 101147. https://doi.org/10.1016/j.pacfin.2019.05.005

Bauer, R., Koedijk, K., \& Otten, R. (2005). International evidence on ethical mutual fund performance and investment style. Journal of Banking \& Finance, 29(7), 1751-1767. https://doi.org/10.1016/j.jbankfin.2004.06.035

Benson, K. L., \& Humphrey, J. E. (2008). Socially responsible investment funds: Investor reaction to current and past returns. Journal of Banking \& Finance, 32(9), 1850-1859. https://doi.org/10.1016/j.jbankfin.2007.12.013

Brzeszczyński, J., \& McIntosh, G. (2014). Performance of portfolios composed of British SRI stocks. Journal of Business Ethics, 120(3), 335-362. https://doi.org/10.1007/s10551-012-1541-x

Cortez, M. C., Silva, F., \& Areal, N. (2009). The performance of European socially responsible funds. Journal of Business Ethics, 87(4), 573-588. https://doi.org/10.1007/s10551-008-9959-x

Consolandi, C., Jaiswal-Dale, A., Poggiani, E., \& Vercelli, A. (2009). Global standards and ethical stock indexes: The case of the Dow Jones Sustainability Stoxx Index. Journal of Business Ethics, 87(1), 185-197. https://doi.org/10.1007/s10551-008-9793-1

Das, P. K., \& Rao, S. U. (2013). Performance evaluation of socially responsible mutual funds using style analysis. Social Responsibility Journal, 9(1), 109-123. https://doi.org/10.1108/17471111311307840

Fama, E. F., French, K. R., Booth, D. G., \& Sinquefield, R. (1993). Differences in the risks and returns of NYSE and NASD stocks. Financial Analysts Journal, 49(1), 37-41. https://doi.org/10.2469/faj.v49.n1.37

Fernandez-Izquierdo, A., \&Matallin-Saez, J. C. (2008). Performance of ethical mutual funds in Spain: Sacrifice or premium?. Journal of Business Ethics, 81(2), 247-260. https://doi.org/10.1007/s10551-007-9492-3

Friend, I., Brown, F. E., Herman, E. S., \& Vickers, D. (1962). A study of mutual funds. Securities Research Unit, Wharton School of Finance and Commerce, University of Pennsylvania. http://3197d6d14b5f19f2f4405e13d29c4c016cf96cbbfd197c579b45.r81.cf1.rackcdn.com/collection/papers/1 960/Wharton_TOC.pdf

Gil-Bazo, J., Ruiz-Verdú, P., \& Santos, A. A. (2010). The performance of socially responsible mutual funds: The role of fees and management companies. Journal of Business Ethics, 94(2), 243-263. https://doi.org/10.1007/s10551-009-0260-4 
Goldreyer, E. F., Ahmed, P., \& Diltz, J. D. (1999). The performance of socially responsible mutual funds: Incorporating sociopolitical information in portfolio selection. Managerial Finance, 25(1). https://doi.org/10.1108/03074359910765830

Hili, J., Pace, D., \&Grima, S. (2016). Equity mutual fund performance evaluation: an emerging market perspective. Contemporary Issues in Bank Financial Management 97, 93-132. https://doi.org/10.1108/S1569-375920160000097009

Humphrey, J. E., \& Lee, D. D. (2011). Australian socially responsible funds: Performance, risk and screening intensity. Journal of Business Ethics, 102(4), 519-535. https://doi.org/10.1007/s10551-011-0836-7

Ippolito, R. A. (1989). Efficiency with costly information: a study of mutual fund performance,1965-1984, The Quarterly Journal of Economics, 104 (1), 1-23. https://doi.org/10.2307/2937832

Jensen, M. C. (1968). The performance of mutual funds in the period 19451964. The Journal of Finance, 23(2), 389-416.

https://doi.org/10.2307/2325404

Jones, S., Van der Laan, S., Frost, G., \& Loftus, J. (2008). The investment performance of socially responsible investment funds in Australia. Journal of Business Ethics, 80(2), 181-203. https://doi.org/10.1007/s10551-007-9412-6

Kreander, N., Gray, R. H., Power, D. M., \& Sinclair, C. D. (2005). Evaluating the performance of ethical and non-ethical funds: a matched pair analysis. Journal of Business Finance \& Accounting, 32(7-8), 1465-1493. https://doi.org/10.1111/j.0306-686X.2005.00636.x

Lozano, J. M., Albareda, L., \& Balaguer, M. R. (2006). Socially responsible investment in the Spanish financial market. Journal of Business Ethics, 69(3), 305-316. https://doi.org/10.1007/s10551-006-9092-7

Lundberg, L., Novák, J., \&Vikman, M. (2009). Ethical vs. non-ethical-is there a difference? Analyzing performance of ethical and non-ethical investment fund (Working Paper No. 22/2009). Institute of Economic Studies. https://www.econstor.eu/bitstream/10419/83335/1/611941228.pdf

Matallín-Sáez, J. C., Soler-Domínguez, A., Tortosa-Ausina, E., \& de Mingo-López, D. V. (2019). Ethical strategy focus and mutual fund management: Performance and persistence. Journal of Cleaner Production, 213, 618-633. https://doi.org/10.1016/j.jclepro.2018.12.130

Mallin, C.A., Saadouni, B., Briston, R.J., 1995. The financial performance of ethical investment funds. Journal of Business Finance and Accounting, 22(4), 483496. https://doi.org/10.1111/j.1468-5957.1995.tb00373.x 
Mill, G. A. (2006). The financial performance of a socially responsible investment over time and a possible link with corporate social responsibility. Journal of Business Ethics, 63(2), 131-148. https://doi.org/10.1007/s10551-005-2410-7

Miller, M. H., \& Modigliani, F. (1961). Dividend policy, growth, and the valuation of shares. The Journal of Business, 34(4), 411-433.

Mishra, P. K. (2012). The nexus between resource mobilization by mutual funds and economic growth in India. Global Business Review, 13(1), 123-136. https://doi.org/10.1177\%2F097215091101300108

Mohanan, S. (2006). Mutual fund industry in India: Development and growth. Global Business and Economics Review, 8(3-4), 280-289. https://www.inderscienceonline.com/doi/abs/10.1504/GBER.2006.010138

Nainggolan, Y., How, J., \& Verhoeven, P. (2016). Ethical screening and financial performance: The case of Islamic equity funds. Journal of Business Ethics, 137(1), 83-99. https://doi.org/10.1007/s10551-014-2529-5

Qureshi, F., Kutan, A. M., Ghafoor, A., Khan, H. H., \& Qureshi, Z. (2019). Dynamics of mutual funds and stock markets in Asian developing economies. Journal of Asian Economics, 65, 101135. https://doi.org/10.1016/j.asieco.2019.101135

Securities and Exchange Board of India (SEBI). (2020). Annual report 2019-20. https://www.sebi.gov.in/reports-and-statistics/publications/feb-2021/annualreport-2019-20_49071.html

Statman, M. (2000). Socially responsible mutual funds (corrected). Financial Analysts Journal, 56(3), 30-39. https://doi.org/10.2469/faj.v56.n3.2358

Sharpe, W. F. (1966). Mutual fund performance. The Journal of Business, 39(1), 119-138. https://www.jstor.org/stable/2351741

Sapar, N. R., \& Madava, R. (2003). Performance evaluation of Indian mutual funds. https://dx.doi.org/10.2139/ssrn.433100

Singh, K., \& Kaur, J. (2021). Does any dynamic interaction between mutual fund and economic growth exist? Evidence from India. International Journal of Indian Culture and Business Management, 23(3), 309-323. http://dx.doi.org/10.1504/IJICBM.2020.10032118

Scholtens, B. (2005). Style and performance of Dutch socially responsible investment funds. The Journal of Investing, 14(1), 63-72.

https://doi.org/10.3905/joi.2005.479390

Social Investment Forum [SIF]. (2020). Report on US sustainable and Impact Investing Trends 2020. https://www.ussif.org/trends/

Sparkes, R., \& Cowton, C. J. (2004). The maturing of socially responsible investment: A review of the developing link with corporate social 
responsibility. Journal of Business Ethics, 52(1), 45-57.

https://doi.org/10.1023/B:BUSI.0000033106.43260.99

Tippet, J. (2001). Performance of Australia's ethical funds. Australian Economic Review, 34(2), 170-178. https://doi.org/10.1111/1467-8462.00186

Traaseth, A. J. R., \& Framstad, U. E. (2016). Ethical investing-A study of performance (Unpublished Master's Thesis). Copenhagen Business School.https://researchapi.cbs.dk/ws/portalfiles/portal/58412315/Anders_Johan_Rustestuen_Traaseth. pdf

Treynor, J. (1965, January-February). How to rate management of investment funds. Harvard Business Review, 43, 63-75

Tripathi, V., \& Bhandari, V. (2015). Do ethical funds underperform conventional funds? Empirical evidence from India. International Journal of Business Ethics in Developing Economies, 4(02), 10-19.

http://www.publishingindia.com/ijbede/51/do-ethical-funds-underperformconventional-funds-empirical-evidence-from-india/430/3264/ 